\title{
Seed Transmission of Hibiscus Latent Ringspot Virus (HLRSV)
}

\author{
C. Rubies-Autonell and M. Turina, Istituto di Patologia Vegetale, Via Filippo Re 8, 40126 Bologna, Italy
}

\begin{abstract}
Rubies-Autonell, C., and Turina, M. 1997. Seed transmission of hibiscus latent ringspot virus (HLRSV). Plant Dis. 81:1082-1084.

Commercial seed lots of various cultivars of kenaf (Hibiscus cannabinus) were shown to transmit hibiscus latent ringspot virus (HLRSV) to progeny seedlings in different percentages up to a maximum of $26 \%$. In these greenhouse tests, no symptoms were observed in the infected seedlings. Enzyme-linked immunosorbent assays (ELISA) of dissected kenaf seeds suggested that seed infection occurs through the embryo. HLRSV was also shown to be seed transmitted in Chenopodium amaranticolor and C. quinoa, in $11 \%$ and in less than $1 \%$, respectively, of the seed collected from mechanically inoculated plants. However, transmission of HLRSV through seed was not detected in Abutilon theophrasti. C. quinoa and C. amaranticolor plants infected through seed transmission were invariably symptomless as opposed to mechanically inoculated plants that exhibited systemic symptoms of yellow flecking.
\end{abstract}

Kenaf (Hibiscus cannabinus L.) has recently become an increasingly important crop in several countries as a potential new source for cellulose (11). Hibiscus latent ringspot virus (HLRSV) was first reported and characterized in $H$. rosa-sinensis from Nigeria $(3,4)$, and since then, reported only in kenaf crops in Italy beginning in the 1992 growing season (15). HLRSV, previously HLRV (3), is a member of the Nepovirus genus (7). The epidemiology of HLRSV is not clear yet, although since the 1992 growing season in the Po Valley and Apulia regions of Italy, the distribution of infected plants in experimental plots of kenaf crops has been scattered (15). This suggested that infected seeds might be a source of primary inoculum for HLRSV infections. A previous attempt to demonstrate seed transmission of HLRSV in Nicotiana clevelandii failed, and no other means of transmission was ever proved $(3,15)$. This study was undertaken to better understand the possible role of HLRSV seed transmission in virus perpetuation, perennation, and dissemination, as well as the eventual economic consequences for the grower.

\section{MATERIALS AND METHODS}

Three different strategies were applied in order to study and quantify seed transmission of HLRSV in Hibiscus cannabinus, Chenopodium quinoa Willd., $C$. amaranticolor Coste et Reyn, and Abutilon theophrasti Med.

Corresponding author: C. Rubies-Autonell
E-mail: crublbet@pop.agrsci.unibo.it

Accepted for publication 6 June 1997.

Publication no. D-1997-0728-03R

(C) 1997 The American Phytopathological Society
Test of seedlings from commercial kenaf seed lots. Kenaf seed lots from different commercial sources and geographical locations (Australia, United States, and France) were tested for HLRSV seed transmission to their progeny seedlings. For some of the lots tested, only the commercial source was known, and it does not necessarily coincide with the area where the seed was originally produced. Some of the seed lots were particularly small in size, as no other seed was commercially available. Seeds were surfacesterilized in trisodium phosphate $10 \%$ $\left(\mathrm{Na}_{3} \mathrm{PO}_{4}\right)$ for $15 \mathrm{~min}(5)$, rinsed with distilled water, and sown in sterilized soil (1:1 turf:sand) in a glasshouse with a temperature of $21 \pm 1^{\circ} \mathrm{C}$ and a 16 -h photoperiod. Stringent measures of isolation, confinement, handling, and insect control were taken to ensure that no outside contamination occurred during the course of this study. All kenaf seedlings were assayed at the 4- to 5-leaf stage, 5 to 6 weeks after planting, by the indirect protein A sandwich enzyme-linked immunosorbent assay method (PAS-ELISA) as previously described (15). The rabbit antiserum to the capsid protein of HLRSV was prepared in our laboratory (15) and used at a 1:500 dilution in phosphate buffered saline (PBS), $0.02 \mathrm{M}$ phosphate plus $0.15 \mathrm{M}$ $\mathrm{NaCl}, \mathrm{pH}$ 7.4. For each plantlet assayed, a portion of the cotyledon and of the youngest emerged leaf were pulverized with a mortar and pestle in 10 volumes of PBS containing $0.05 \%$ Tween $20,2 \%$ polyvinylpyrrolidone (MW 24,000), $0.13 \%$ sodium sulfite, and $0.2 \%$ ovalbumin. For each ELISA, known positive (both purified virus at known concentration and crude extract at $1 / 10$ dilution) and negative healthy control to each plant species were included. Samples with absorbance values at $A_{405 \mathrm{~nm}}$ of at least 3 times the healthy control were considered positive, and those with an absorbance of between 2 and 3 times the healthy control were checked biologically by mechanical back inoculation to $C$. amaranticolor plants.

Kenaf seeds harvested from plants naturally infected with HLRSV. Periodical surveys to detect naturally infected plants were carried out in experimental kenaf fields situated in the Apulia Region and in the Po Valley during the 1992, 1993, and 1994 growing seasons. Our access to the experimental plots, which contained seed from a large number of geographical sources (Australia, United States, Central America, Thailand, Russia, France, and Italy), was kindly permitted by the Agronomy Department of the University of Bologna. The plots were part of a variety trial sown in mid-May of each year. Individual plants in each plot were chosen by their stunted appearance, labeled, and tested for HLRSV by PAS-ELISA. Kenaf plants that tested positive for HLRSV were periodically retested throughout the growing season, and their seeds were subsequently harvested either to directly test for HLRSV seed infection or to evaluate the frequency of seed-transmission of the virus to progeny seedlings. Each kenaf seedling was tested individually for HLRSV.

Test of HLRSV transmission through seed harvested from HLRSV mechanically inoculated plants. $C$. quinoa and $C$. amaranticolor plants were inoculated at the fifth-leaf growth stage and grown in controlled environment at $21 \pm 1^{\circ} \mathrm{C}$ until seed production. Mechanical inoculation of kenaf and $A$. theophrasti plants was performed in a field near Bologna at the end of June 1994. Kenaf plants belonging to the most precocious cultivars (G4, Uzbesky, and Cuba 961) were inoculated at their sixth- or seventh-leaf growth stage as previously described (15). A. theophrasti was inoculated at the tenth-leaf growth stage.

The mechanically inoculated plants were monitored for symptom severity and HLRSV infection through periodic surveys and PAS-ELISA. Seeds of the infected plants were collected at maturity and stored in the dark at $4^{\circ} \mathrm{C}$. Seeds were surface-sterilized and sown in sterilized soil as described above. A. theophrasti, $C$. Amaranticolor, and $C$. quinoa seedlings were assayed in bulks of five leaves (one leaf from each individual seedling). Positive groups of leaves were assayed again as single plant samples.

Virus detection in kenaf whole seed and in kenaf seed parts. To test individ- 
ual seeds from one commercial lot, 312 seeds from cultivar G4 from Australia were soaked in $10 \% \mathrm{Na}_{3} \mathrm{PO}_{4}$ for $30 \mathrm{~min}$ and washed three times with distilled water. Following imbibition in water for $3 \mathrm{~h}$, individual seeds were ground with a mortar and pestle in the extraction buffer described previously at a 1:5 (wt/vol) dilution. PAS-ELISA was used to assay virus infection of whole seed, and any HLRSV external contamination of the seed tegument was determined by assay of the first and third water washes.

To test the viral content of specific seed parts, after disinfection and imbibition as above, 55 seeds were dissected carefully with sterile forceps into embryo, endosperm, and internal and external tegument. Each individual dissected portion of the seed was soaked in $10 \% \mathrm{Na}_{3} \mathrm{PO}_{4}$ for 15 min and rinsed three times before being pulverized with a probe on a slide under a binocular microscope at 10 to $15 \times$ magnification.

\section{RESULTS}

HLRSV infection in seedlings from commercial kenaf seed lots. Results of the ELISA of the progeny seedlings from six commercial kenaf seed lots confirmed seed transmission ranging from 0 to $26 \%$ (Table 1). No obvious symptoms were associated with the infected seedlings at the five-leaf growth stage of the analysis.

Seed transmission from HLRSV naturally infected plants. HLRSV was detected in several randomly distributed plantlets approximately 20 days after sowing in all years during the survey. The infected plants were stunted, and the leaves were mildly chlorotic.

During 1993 and 1994, we detected a few HLRSV-infected plants in the experimental plots at Bologna that were planted with cultivars Khon Kaen 60, G4, Taynung 1, Everglades 71, Everglades 41, BG 5238, Uzbesky, Mal 1, Cuba 108, and 977-044 from a large number of geographical sources (Australia, United States, Central America, Thailand, Russia, France, and Italy). In both years, 42 HLRSV-infected plants were chosen out of those tested from these fields and labeled for periodic surveys during the growing season. Of the surveyed plants, 30 of the G4 cultivar and 5 each of Taynung 1 and Khon Kaen 60 cultivars exhibited abnormal growth and development, including stunting and thinner stands, when compared with kenaf that tested negative for HLRSV. In addition, the infected plants did not flower or produce seeds at our latitude (northern Italy). Only two HLRSV-infected plants, cultivar Khon Kaen 60 and G4, grown in the Apulia region of southern Italy, produced seed, but all of their seedling progeny (132 Khon Kaen 60 seedlings and 12 G4 seedlings) tested negative for HLRSV by PAS-ELISA.

HLRSV seed transmission in mechanically inoculated plants. $C$. amaran- ticolor and $C$. quinoa plants showed systemic flecking symptoms 1 week after mechanical inoculation. However, after 2 months, the same HLRSV-infected plants were symptomless in the new emerging leaves but still positive for HLRSV coat protein. The plants subsequently flowered and produced viable seeds. This suggests an apparent recovery phase. Quantitative PAS-ELISA showed that the concentration of capsid protein was not significantly different from symptomatic or asymptomatic leaf tissue of Chenopodium spp. (data not shown). A. theophrasti carried a symptomless HLRSV infection throughout its life cycle.

Seeds collected from HLRSV-infected Chenopodium spp. or Abutilon had a normal appearance, and the seedlings that subsequently tested positive from the seed transmission assays were indistinguishable from noninfected seedlings. Percentage of seed transmission is summarized in Table 2 . In addition, the infected or healthy mature plants were symptomless and indistinguishable in growth habit. Mechanical back inoculation to $C$. amaranticolor from symptomless infected seedlings of all the species studied resulted in strong systemic yellow flecking, indistinguishable from the typical HLRSV symptoms observed on

Table 1. Hibiscus latent ringspot virus (HLRSV) infection rates of plantlets from commercial kenaf seed lots and their geographical or commercial source

\begin{tabular}{lcccc}
\hline & & \multicolumn{3}{c}{ Number of plantlets } \\
\cline { 3 - 5 } Cultivar & $\begin{array}{c}\text { Geographical } \\
\text { source }^{\mathbf{a}}\end{array}$ & Tested & $\begin{array}{c}\text { HLRSV } \\
\text { infected }^{\mathbf{b}}\end{array}$ & $\begin{array}{c}\text { Transmission } \\
\text { rate (\%) }\end{array}$ \\
\hline G4 & Australia & 441 & 114 & 26 \\
Taynung 1 & United States & 303 & 28 & 9 \\
G4 & United States & 94 & 16 & 17 \\
G4 & United States & 100 & 0 & 0 \\
Everglades 41 & United States & 50 & 0 & 0 \\
BG 5238 & France & 40 & 0 & 0 \\
\hline
\end{tabular}

${ }^{a}$ The seed lot from Australia was also produced in Australia. The production locations of the other seed lots are not known.

b Seedlings and whole seeds were assayed for HLRSV by protein A sandwich enzyme-linked immunosorbent assay (PAS-ELISA).

Table 2. Hibiscus latent ringspot virus (HLRSV) seed transmission rates from mechanically inoculated plants

\begin{tabular}{lccc}
\hline & \multicolumn{3}{c}{ Number of plantlets } \\
\cline { 2 - 4 } Species & Tested & HLRSV infected $^{\text {a }}$ & $\begin{array}{c}\text { Seed transmission } \\
\text { rate (\%) }\end{array}$ \\
\hline Chenopodium amaranticolor & 510 & 60 & 12 \\
C. quinoa & 1,167 & 7 & $<1$ \\
Abutilon theophrasti & 562 & 0 & 0 \\
\hline
\end{tabular}

a Seedlings and whole seeds were assayed for HLRSV by protein A sandwich enzyme-linked immunosorbent assay (PAS-ELISA).

Table 3. Whole seed assay for hibiscus latent ringspot virus (HLRSV) presence

\begin{tabular}{|c|c|c|c|}
\hline \multirow[b]{2}{*}{ Species } & \multicolumn{3}{|c|}{ Number of seeds } \\
\hline & Tested & HLRSV infected ${ }^{a}$ & Infected seed $(\%)$ \\
\hline Hibiscus cannabinus (cv. G4) & 312 & 159 & 51 \\
\hline Chenopodium quinoa & 133 & 6 & 5 \\
\hline
\end{tabular}


ments gave negative results in PASELISA.

\section{DISCUSSION}

This is the first report of seed transmission of HLRSV, and it brings to 19 the number of known Nepoviruses transmitted by seed (13). In our research, transmission of HLRSV was demonstrated to occur in three different species, including its natural host, $H$. cannabinus, whose importance as an industrial crop is already relevant in tropical and subtropical areas. The possibility of adapting its cultivation to European countries is under investigation. Previous reports indicated that HLRSV could not be seed transmitted (4). This now appears to be due to the different host $(N$. clevelandii, which our isolate fails to infect) and the different isolate used (HLRSV from kenaf from Italy instead of HLRSV from $H$. rosa sinensis isolated in Nigeria [4]). Moreover, the small size of the sample tested in the previous study (4) might account for an escape of a very low transmission rate in the host tested. It is not uncommon to find extremes of seed transmission rates when tested in different plant species or cultivars $(6,18)$

HLRSV presence in the first seed wash runoff tested by PAS-ELISA proves the presence of antigen on the seed surface, although retention of infectivity after trisodium phosphate treatment excludes seed transmission from viable virus contaminant of seed surface (5). Consistent presence of the virus in the embryo of the infected seed lots suggests that infection of the progeny seedling occurs through the embryo. However, from these data, we cannot state if the infection of the embryo occurs through direct or indirect invasion according to the distinction previously reported (10).

We detected HLRSV in $51 \%$ of the kenaf cv. G4 tested seed, but only $26 \%$ of the progeny derived from the same seed lot were infected. A similar result was noticed in C. quinoa (5\% of the seed as opposed to less than $1 \%$ of the plantlets). Our data confirm that the incidence of seed transmission by viruses does not necessarily correlate with the rate of infected progeny seedling $(10,13)$.

Our inability to obtain mature seed from naturally infected kenaf plants is probably due to the general difficulties in obtaining seeds at our latitude (Bologna, northern Italy) and to the fact that we selected plants with a weak appearance. This would result in the escape of infected but competitive individuals from our surveys. On the other hand, the two infected plants that produced viable seeds are too small a sample to draw any conclusions. Determination of seed transmission rate through symptom monitoring of the infected plantlets in greenhouse condition demonstrated to be unreliable, since HLRSV infection through seed was invariably symptomless. Moreover, the association between a weak appearance and HLRSV infection was not always constant in open field condition.

The lack of symptoms in HRLSV-positive plants derived from infected seed is an unusual phenomenon even if milder symptoms are quite a common feature of seed-transmitted infected seedlings particularly in other seed transmissible Nepoviruses such as tobacco ringspot virus (TRSV) and tomato black ring virus (TBRV) $(9,17)$. This will be important in being able to derive kenaf breeding lines that are HLRSV free. A previous explanation has been suggested for the lack of symptoms of the plants infected through seeds compared with those infected by mechanical inoculation, linking it to an explanation of the recovery phase often observed in viruses belonging to the Nepovirus group $(1,12,14)$. However, a precise molecular mechanism of this phenomenon has not been studied yet. Our data prove that the virus in the symptomless plants is infectious, as mechanical inoculation of pulverized leaves to indicator species produces typical wild type HLRSV symptoms and both the symptomless and inoculated plants are positive by ELISA. Particularly interesting is that seed production in the Chenopodium species studied occurs after the mechanically infected plant recovers from infection, suggesting an evolutionary advantage in seed transmission for viruses able to go through a recovery phase, as the differentiation of the floral meristematic apex seems no longer to be affected.

The rate of seed transmission is not necessarily a good indicator of epidemiological significance, and in our case, as rather high seed transmission rate is linked to lack of spread within the field by any known vector in our environment, the incidence of the disease does not seem to increase during the growing season. However, we cannot exclude a more severe infection if a secondary infection spread by a yet unknown vector occurs.

We suggest that all the germ plasm collected and characterized should be surveyed for HLRSV presence by a suitable method, such as ELISA, as symptoms are not a reliable indicator of HLRSV infections in kenaf. The potential for inadvertent dispersal of the virus during a latent phase within global programs of genetic improvement (8) is suggested by the data presented during this study.

In addition, although there is no data on the effects of viral infection in relation to the genetic stability of Hibiscus spp., research on maize and barley stripe mosaic virus indicates that there is a link between viral infection and a higher mutation rate of some host characters taken into consideration, described by the aberrant ratio studies $(2,16)$. The disturbance of a virus infection on the genetic stability of its plant host has to be taken into consideration in any breeding program, particularly when a latent infection might easily escape detection based on symptom expression, as in the case of the Hibiscus-HLRSV system.

\section{ACKNOWLEDGMENTS}

The authors gratefully acknowledge the helpful reviews and comments of Karen-Beth G. Scholthof. The work was supported by the CITECA project.

\section{LITERATURE CITED}

1. Benda, G. T. A., and Naylor, A. W. 1958. On the tobacco ringspot disease. III. Heat and recovery. Am. J. Bot. 45:33-37.

2. Brakke, M. K. 1984. Mutations, the aberrant ratio phenomenon, and virus infection of maize. Annu. Rev. Phytopathol. 22:77-94.

3. Brunt, A. A., Barton, R. J., and Phillips, S. 1981. Hibiscus latent ringspot virus. C.M.I./A.A.B. Description of plant viruses $\mathrm{N}^{\circ}$ 233.

4. Brunt, A. A., Barton, R. J., Phillips, S., and Lana, O. 1980. Hibiscus latent ringspot virus: A newly recognised virus from Hibiscus rosasinensis (Malvaceae) in western Nigeria. Ann. Appl. Biol. 96:37-46.

5. Demski, W. 1981. Tobacco mosaic virus is seedborne in pimento peppers. Plant Dis. 65:723-724.

6. Edwards, M. C. 1995. Mapping of the Seed Transmission Determinants of Barley Stripe Mosaic Virus. Mol. Plant-Microbe Interact. 8:906-915.

7. Goldbach, R., Martelli, G. P., and Milne, R G. 1995. Family Comoviridae. Pages 341-347 in: Virus Taxonomy. F. A. Murphy, C. M Fauquet, D. H. L. Bishop, S. A. Ghabrial, A W. Jarvis, G. P. Martelli, M. A. Mayo, and M D. Summers, eds. Springer-Verlag, Wien.

8. Hampton, R. O. 1983. Seed-borne viruses in crop germplasm resources: Disease dissemination risks and germplasm-reclamation technology. Seed Sci. Technol. 11:535-546.

9. Hanada, K., and Harrison, B. D. 1977. Effects of virus genotype and temperature on seed transmission of nepoviruses. Ann. Appl. Biol. 85:79-92

10. Johansen, E., Edwards, M. C., and Hampton, R. O. 1994. Seed transmission of viruses: Current perspectives. Annu. Rev. Phytopathol. 32:363-386.

11. Kaldor, A. F., and Aust, M. I. E. 1996. Issues Related to the Establishment of Large Scale Kenaf Industries in USA, Europe, Asia and Australia. Eur. Symp. Ind. Crops Products, 3rd, Reims Champagne Congres, Reims, France. p. 84.

12. Lister, R. M., and Murant, A. F. 1967. Seedtransmission of nematode-borne viruses. Ann. Appl. Biol. 59:49-62.

13. Mink, G. I. 1993. Pollen- and seed-transmitted viruses and viroids. Annu. Rev. Phytopathol. 31:375-402.

14. Murant, A. F. 1983. Seed and pollen transmission of nematode-borne viruses. Seed Sci. Technol. 11:973-987.

15. Rubies-Autonell, C., and Turina, M. 1995. Characterization and cytopathology of hibiscus latent ringspot virus isolated from kenaf (Hibiscus cannabinus L.) in Italy. J. Phytopathol. 143:211-215.

16. Sprague, G. F., and McKinney, H. H. 1966. Aberrant ratios: An anomaly in maize associated with virus infection. Genetics 54:12871296

17. Tuite, J. 1960. The natural occurrence of tobacco ringspot virus. Phytopathology 50:296-298.

18. Wang, D., Woods, R. D., Cockbain, A. J. Maule, A. J., and Biddle, A. J. 1993. The susceptibility of pea cultivars to pea seed-borne mosaic virus infection and virus seed transmission in the UK. Plant Pathol. 42:42-47. 